\title{
Decline of democracy-the European Union at a crossroad
}

\section{Theresia Smolka}

\begin{abstract}
Although EU member states have committed themselves to upholding the fundamental democratic values enshrined in Article 2 Treaty on European Union, violations of these values could be observed in some member states-first and foremost in Hungary and Poland. This article studies whether these negative developments, which are often summarized under the terms backsliding or erosion of democracy, should be classified as a loss in the quality of democracy or even as a decline of democracy. By drawing on Gero Erdmann's (2011) theoretical definition of decline of democracy and using Democracy Barometer data for the period between 2004 and 2016, this form of loss of the quality of democracy is analysed for the $28 \mathrm{EU}$ member states. In addition, the EU's role in safeguarding democracy in its member states is discussed. The article shows that it is not only the new EU members that show a decline of democracy more frequently, but the old EU members. The EU as guardian of the democratic fundamental values is failing to live up to its role despite the numerous instruments it has at its disposal.
\end{abstract}

Keywords Decline of democracy - Quality of democracy · European Union • Democracy Barometer · Backsliding · Erosion of democracy $\cdot$ EU member states

Dr. T. Smolka $(\bowtie)$

Berlin, Germany

E-Mail: theresia.smolka@gmail.com

Universität Duisburg-Essen, Duisburg, Germany 


\section{Decline of Democracy - die Europäische Union am Scheideweg}

Zusammenfassung Obwohl sich alle EU-Mitgliedsstaaten zur Wahrung der in Artikel 2 EU-Vertrag verankerten demokratischen Grundwerte verpflichtet haben, sind bei einigen Mitgliedsstaaten - allen voran bei Ungarn und Polen - Verstöße gegen diese zu beobachten. Dieser Artikel untersucht, ob diese negativen Entwicklungen, die oft unter den Begriffen Rückfall oder Erosion der Demokratie zusammengefasst werden, als Verlust der Qualität der Demokratie oder decline of democracy zu klassifizieren sind. Unter Rückgriff auf Gero Erdmanns (2011) theoretische Definition von decline of democracy und unter Verwendung des Demokratie Barometers wird für den Zeitraum zwischen 2004 und 2016 diese Form der Rückentwicklung der Demokratiequalität für die 28 EU-Mitgliedstaaten analysiert. Darüber hinaus wird die Rolle der EU bei der Sicherung der Demokratie in ihren Mitgliedsstaaten diskutiert. Es zeigt sich, dass nicht nur die neuen EU-Mitglieder - wie in der Literatur oft beschrieben - häufig einen decline of democracy aufweisen, sondern auch die alten EU-Mitglieder stark betroffen sind. Zudem zeigt sich eindrücklich, dass die EU ihrer Rolle als Hüterin der demokratischen Grundwerte trotz zahlreicher Instrumente nicht gerecht wird.

Schlüsselwörter Decline of democracy · Demokratiequalität · Europäische Union · Demokratie Barometer · Rückfall der Demokratie - Rückentwicklung der Demokratiequalität $\cdot$ EU-Mitgliedsstaaten

\section{Introduction: Signs of erosion in the quality of democracy in EU member states}

All European Union (EU) member states must comply with the Copenhagen Criteria (1993) and commit to upholding the conditions set out in Article 2 of the Treaty on European Union (TEU), namely "the values of respect for human dignity, freedom, democracy, equality, the rule of law, and respect for human rights [...]" (European Union 2007). The EU is so far the only supranational organization that ties membership to the fulfilment of democratic and constitutional conditions (Kneuer 2007). In addition, the EU has numerous instruments at its disposal for sanctioning deviant behaviour (including Article 7 TEU, infringement procedures), and can thus be described as a promoter and guardian of democratic principles in its member states (Schimmelfennig 2009).

However, democracy in the EU has faced challenges for almost 15 years now. As early as 2007, the Nations in Transit Report identified anti-democratic tendencies in the young Central and Eastern European member states (Puddington 2011; Walker and Habdank-Kolaczkowska 2012). Erosions ${ }^{1}$ of democracy have progressed furthest in Hungary and Poland: In Hungary, the concentration of power of the national

\footnotetext{
${ }^{1}$ The terms erosion, deterioration and loss of democracy are used synonymously in the article to refer to the loss of the quality of democracy. The decline of democracy, on the other hand, is a term in its own right and represents a special form of the loss of the quality of democracy.
} 
populist party Fidész under Prime Minister Victor Orbán has steadily increased since 2010. As a result, in 2018, Hungary became the first EU member state ever to be classified as partially free by Freedom House (Freedom House 2019; IDEA 2021). Poland has also seen continuous erosions since the Prawo i Sprawiedliwość (PiS) party came to power, such as a series of measures that undermine the independence of the judiciary, allow PiS to dominate the media, and silence criticism from civil society (Freedom House 2019). Neither Hungary nor Poland could join the EU, were they not members already, as they currently no longer meet the Copenhagen criteria (Sapper and Weichsel 2018). Developments that threatened media independence were also observed in other EU countries such as the Czech Republic and Slovakia in 2018 (Freedom House 2019). In addition, far right parties such as Vox in Spain, made electoral gains. In some cases they even entered government (e.g. Estonia in 2020, Austria in 2017, Freedom House 2020). Croatia, Lithuania, Bulgaria and Romania faced problems in the fields of corruption and organized crime as well as in the independence of the judiciary (Merkel 2010, p. 39). Nevertheless, the risk of a reverse wave in young or even old democracies was hardly addressed in the literature until the mid-2000s. Since then, scholars have published studies that tend to be rather pessimistic about the evolution of democracy-including predictions of a decline of democracy ${ }^{2}$ or a reverse wave (Diamond 2008, 2015; Puddington 2008a). This assessment is not shared by everyone, though (Levitsky and Way 2015; Schmitter 2015).

Many studies analysing erosions in the quality of democracy are based on the assessment of individual cases (Ágh 2016; Andersen 2006; Krekó and Enyedi 2018) or a small set of cases (Frankenberger and Graf 2011; Ganev 2013; Kneuer 2011). Studies dealing with a middle or a large set of cases are relatively rare (Erdmann 2011; Svolik 2008). Studies dealing with EU member states focus mainly on Central and Eastern European countries (Bochsler and Juon 2020; Kapidžić 2020; Kelemen 2020; Ziemer 2020) since young democracies are considered to be particularly vulnerable to detrimental systemic developments (Erdmann 2011; Pickel 20123). But there is hardly any systematic comparative analysis dealing with the decline of democracy in all 28 EU member states (Smolka 2019). Moreover, many studies rely on democracy measures such as Freedom House, Polity IV or Bertelsmann Transformation Index, which cannot map gradual changes in the quality of democracy (Bühlmann et al. 2012, p. 520; Erdmann 2011, p. 39, 44; Pickel 2012, p. 24; Pickel et al. 2015, p. 497, 2016, p. 2).

This article seeks to fill this gap by examining whether signs of erosions of democracy in EU member states reflect losses in the quality of democracy or even a decline in democracy, and whether patterns can be deduced. In addition, the role

\footnotetext{
2 Not only does the terminology differ in the literature, but the criteria describing the deterioration in the quality of democracy also differ. Erdmann and Kneuer (2011) for instance use the term "regression of democracy", Erdmann (2011) and Schmitter (2015) name the process "decline of democracy" and Levitsky and Way (2015) describe it as "democratic regression".

3 Pickel, Gert. 2012. Deterioration of Democratic Quality. Comparative Analyses on their Cultural and Structural Conditions. unveröffentlichtes Manuskript.

4 Pickel, Gert. 2012. Deterioration of Democratic Quality. Comparative Analyses on their Cultural and Structural Conditions. unveröffentlichtes Manuskript.
} 
of the EU in terms of its ability to prevent such developments in its member states is discussed. This is all the more important because the member states have committed themselves to fulfilling the Copenhagen criteria and stable and functioning democracies in the member states are crucial for the functioning of the EU. I rely on Bühlmann et al.'s (2008a) theoretical concept of quality of democracy and Erdmann's (2011) definition of a decline of democracy. The Democracy Barometer data set-an index designed to measure the quality of democracy-is used to analyse the decline of democracy in the 28 EU member states between 2004 and 2016. In addition, the role of the EU as a guardian of democracy and the rule of law in its member states is discussed. I expect that the new EU member states ${ }^{5}$ are affected more often from a decline of democracy than the old ones. My expectation is based on the assumption that young democracies are more prone to cycles of democratic gains and regressions (Pickel 2012) ${ }^{6}$. Findings (Pickel 2012) ${ }^{7}$ indicate a positive influence of the democratic establishment on its stability, i.e. the length of time a country is a democracy. In addition, the majority of reports on violations of democratic principles refer to the new member states of the EU. Restrictions of civil liberties such as freedom of the press are frequently mentioned, but also attacks on the rule of law. Therefore, I assume that the principle of freedom is more often affected by erosions than the principles of equality and control.

The remainder of this article is organized as follows. Section two elaborates the theoretical concept of the quality of democracy and the decline of democracy, from which the criteria for the empirical analysis are derived. Section three presents the research design, including case selection, data description and operationalization of a decline of democracy. The criteria from section two are used in section four to empirically analyse whether the EU member states show losses in the quality of democracy or declines of democracy. Based on the existing literature, section five briefly discusses the EU's role in combating decline of democracy in its member states. The final section concludes.

\section{Democracy - quality and decline}

\subsection{The quality of democracy}

"The analysis of the quality of democracy - that is an empirical scrutiny of what 'good' democracy is about-requires not only that we have a definition of democracy but also that we establish a clear notion of quality" (Morlino 2004, p. 5). The notion of democracy that underlies the concept of quality of democracy is thus crucial for

\footnotetext{
5 New EU member states include the ten countries (eight Central and Eastern European countries plus Cyprus and Malta) that joined the EU in 2004 as well as Bulgaria, Romania and Croatia which became members in 2008 and 2013, respectively.

6 Pickel, Gert. 2012. Deterioration of Democratic Quality. Comparative Analyses on their Cultural and Structural Conditions. unveröffentlichtes Manuskript.

7 Pickel, Gert. 2012. Deterioration of Democratic Quality. Comparative Analyses on their Cultural and Structural Conditions. unveröffentlichtes Manuskript.
} 
the analysis of the quality of democracy and the decline of democracy (OsterbergKaufmann et al. 2020, p. 301). In recent years, numerous researchers have presented different conceptualizations of the quality of democracy at the macro level (Munck 2016; Pickel et al. 2015). It is generally agreed upon that "the concept [quality of democracy, T.S.] is applicable only to those cases that have been determined [...] to meet the standard of the baseline concept of democracy" (Munck 2016, p. 9). In this regard, minimalist definitions of democracy (e.g. Dahl 1971) are considered inadequate because they do not allow researchers to capture the concept of democracy by degree (Erdmann 2011; Morlino and Carli 2014). By contrast, Merkel et al. (2003) provide a sophisticated mid-range definition of democracy. It goes beyond the electoral principle and includes other liberal functions of democracy such as the rule of law (Bochsler and Juon 2020).

Merkel et al. (2003, p. 47) define democracy as a set of institutional minima containing, first, a vertical dimension of democratic rule, namely vertical checks on the balance of power, the right of active and passive suffrage and effective fundamental participation rights. Second, it comprises a horizontal dimension, that is checks and balances. Third, it has a transversal dimension, namely the assignment of the effective power to govern to democratically legitimized rulers. The three dimensions of the definition correspond to the three fundamental principles of democracy, which are equality, freedom and control. The definition by Merkel et al. (2003) does not consider any outcomes of democracy, focusing solely focus on structures and procedures of a democratic system. They mainly capture participation and representation in terms of "government of the people and by the people" (Lincoln Gettysburg Address 1863) (Siaroff 2009). The definition of democracy by Merkel et al. (2003) is further elaborated as the one by Dahl (1971), but it is still based on the basic theoretical principles of democracy. Furthermore, the definition includes Merkel et al.'s (2003) model of a liberal democracy (embedded democracy) and, accordingly, the theoretical basis of the Democracy Barometer (DB).

The concept of the quality of democracy on which the DB is based (Bühlmann et al. 2008b) and the one developed by Diamond and Morlino (2005) and Morlino (2009) are among those that have strongly influenced the debate. Unlike Bühlmann et al. (2008a), Diamond and Morlino (2005) present a substantial definition of the quality of democracy (Pickel et al. 2016). ${ }^{8}$ It is not taken into consideration, since the definition of democracy used in this article is a procedural one and does not contain any outcomes. Consequently, the theoretical approach presented by Bühlmann et al. (2008b), which is seen as one of the most profound theoretical approaches (Munck 2016), is used. Their concept of the quality of democracy is based on Merkel et al.'s (2003) definition of a liberal democracy and the concept of the embedded democracy. Thus, the three fundamental principles of democracy-political equality, freedom and control of power-are at the core of their concept. From the three principles, they theoretically derive nine democratic functions (transparency, participation, representation, individual liberties, rule of law, public sphere, competition,

\footnotetext{
8 Diamond and Morlino (2005) and Morlino (2009) define quality of democracy in terms of process, content and result. Thus, they link the procedural with the substantial dimensions and evaluate the government's policy results with respect to the citizens' expectations.
} 
mutual constraints and government capability) which are further disaggregated into 18 components, 51 subcomponents ${ }^{9}$ and 98 indicators (Bühlmann et al. 2012; Engler et al. 2020). ${ }^{10}$ The quality of democracy depends on the degree to which the principles, functions and its components are fulfilled (Bühlmann et al. 2007). The authors assume that the quality of a democracy is high if the nine functions are fulfilled to a high degree. Nevertheless, he points out that the simultaneous maximization of all nine functions is not possible due to the existing tensions between freedom and equality. Since democracies are systems whose development is constantly negotiated by political and social forces, democracies can weight and optimize the nine functions differently and thus influence the quality of their democracy.

\subsection{The decline of democracy}

As one of the few researchers, Erdmann (2011) has theoretically conceptualised the decline of democracy. He terms the reverse process of democratization-i.e. the transformation from democracy, starting with the loss of quality - as decline of democracy. Erdmann defines the decline of democracy as "[...] a deterioration of quality in one of the two central dimensions of democracy-freedom and equality-and in one additional one, i.e. the (horizontal) control of power; it describes a negative variation within the democratic regime type" (Erdmann 2011, p. 24). A democratic political system can show a decline in quality and then turn into a defective democracy, a hybrid or an authoritarian regime. The process can be either slow and gradual, moving from quality loss to a hybrid regime, or fast and short, ending in an authoritarian or totalitarian regime without passing through the hybrid stage. In line with research on the consolidation of democracy, three types of decline of democracy can be derived: a silent regression, i.e. a gradual decrease in freedoms, rights and processes which are important for democracy (O'Donnell 1995, p. 25), a backslide, i.e. a relapse from democracy into a hybrid regime, and a breakdown, i.e. the collapse of democracy. From an empirical perspective the most common patterns are silent regressions and backslides, whereas breakdowns are relatively rare (e.g. Venezuela, Thailand and Honduras; Erdmann 2011, p. 28; Erdmann and Kneuer 2011, p. 13; Levitsky and Way 2015, pp. 52-53).

To date, several approaches have addressed the decline of democracy mainly in terms of regime change "but not as a decline in the quality of democracy" (Erdmann 2011, p. 39). In liberal democracies, the decline of democracy can result in a significantly lower level of quality which can lead to the classification of a liberal democracy as a diminished subtype of democracy, such as a defective democracy (Merkel 2004), an electoral democracy (Diamond 1999; Erdmann 2011) or illiberal, inegalitarian or unaccountable democracies (Lauth et al. 2021). Declines in the quality of liberal democracy are more nuanced than in the case of regime changes. As early as 1996, Huntington pointed out the danger of a gradual regression of democ-

\footnotetext{
9 Each component is measured by subcomponents which measure legal rules as well as the effective constitutional reality (Bühlmann et al. 2007).

10 In former versions of the DB there were 105 indicators and 53 subcomponents. For a short description of the composition of the nine functions see Bühlmann et al. (2012a) or Engler et al. (2020).
} 
racy in the young democracies of the third wave of democratization: "the problem is not overthrow but erosion: the intermittent or gradual weakening of democracy by those elected to lead it" (Huntington 1996, p. 8). Merkel and Puhle Merkel and Puhle (1999) also saw the danger of a creeping erosion, hollowing out and de-liberalization of young democracies by freely elected governments. Consequently, the literature often refers to the age of a democracy as an important factor in a democracy's susceptibility to deteriorations in the quality of democracy (Erdmann 2011; Erdmann and Kneuer 2011; Pickel 2012 ${ }^{11}$; Svolik 2008). It is assumed that young democracies - especially those of the third wave of democratization after 1989-are more prone to a decline in the quality of democracy because they have a lower degree of institutionalization and consolidation than political systems that have been democracies for a longer period of time. Moreover, young democracies are supposed to get more often caught in cycles of democratic gains and setbacks (Pickel 2012 ${ }^{12}$ ). But even established industrialized democracies such as the United States under president Trump (Freedom House 2020) have experienced declines in their quality of democracy since the end of the Cold War (Erdmann 2011). Thus, the decline of democracy mainly affects young democracies founded during the third wave of democratization but old democracies are also not immune to it (Diamond 2015, p. 142; Erdmann 2011, p. 28; Erdmann and Kneuer 2011, p. 12; Pickel 2012, p. $2^{13}$ ). A reduction in quality is possible at any time and at any stage of the development of a democracy.

Assumption 1: Within the European Union, a decline of democracy occurs more frequently in the new EU member states than in the old member states.

Within the recent past, violations of basic democratic principles have been recorded in several new EU member states. Civil liberties and political freedoms have been particularly affected, such as the inadequate protection of the freedom of the press, political pluralism or the rule of law in Hungary, Poland and Slovenia. For example, in Hungary the new media law (2010) and the fourth amendment to the constitution (2013) came into force. In 2018 Victor Orbán enacted the Anti-NGO Bill (Otto 2021). Poland's ruling party, the PiS, for instance restricted women's and LGBTQI+-rights in the recent past and in 2020 the Polish Constitutional Court declared abortion laws unconstitutional. In Slovenia, Janez Janša restricted the freedom of expression by attacking critical public media outlets in 2020 (Kube et al. 2020 , p. 13). Occasional violations of civil liberties have also been observed in old EU member states. In Italy, for instance, press freedom was severely restricted under Berlusconi in 2009.

\footnotetext{
11 Pickel, Gert. 2012. Deterioration of Democratic Quality. Comparative Analyses on their Cultural and Structural Conditions. unveröffentlichtes Manuskript.

12 Pickel, Gert. 2012. Deterioration of Democratic Quality. Comparative Analyses on their Cultural and Structural Conditions. unveröffentlichtes Manuskript.

13 Pickel, Gert. 2012. Deterioration of Democratic Quality. Comparative Analyses on their Cultural and Structural Conditions. unveröffentlichtes Manuskript.
} 
Assumption 2: Of the three basic democratic principles, freedom rights are more frequently affected by deteriorations than the principles of equality and control.

Whether the negative trends in the quality of democracy predicted since the first half of the 2000s (Diamond 2008, 2015; Puddington 2008) and observed in several regions of the world (Lührmann et al. 2019) also apply in principle to the EU member states needs to be verified. In addition, the assumption that young democracies have a higher susceptibility to deteriorations in the quality of democracy and a decline of democracy compared to old democracies needs to be analysed (Erdmann 2011; Pickel 201214; Puddington 2011; Walker and Habdank-Kolaczkowska 2012). The fear that we could be at the beginning of a reverse wave of democratization, especially in the Central and Eastern European countries, can also be assessed in this way (Diamond 2015).

\section{Research design}

\subsection{Case selection and data}

In the analysis, I study all member states that successfully completed the EU accession process according to article 49 TEU. ${ }^{15}$ Hence, 28 member states are analysed. All countries joining the EU must have "[...] achieved stability of institutions guaranteeing democracy, the rule of law, human rights and respect for and protection of minorities [...]" (European Council 1993, p. 12)—i.e. at the stage of accession, the member states must be consolidated democracies. ${ }^{16}$ This condition is also relevant for the assessment of a decline of democracy because " $[\mathrm{u}]$ nless democratic elements have been established they cannot vanish" (Pickel 2012, p. 4) ${ }^{17}$. The starting point of the analysis is the year 2004, the year of accession of the eight Central and Eastern European countries as well as Cyprus and Malta. ${ }^{18}$ As second, third and fourth

\footnotetext{
14 Pickel, Gert. 2012. Deterioration of Democratic Quality. Comparative Analyses on their Cultural and Structural Conditions. unveröffentlichtes Manuskript.

15 Article 49 TEU says: "Any European State which respects the values referred to in Article 2 and is committed to promoting them may apply to become a member of the Union." (Eur-Lex 2012). The values in article 2 are described as follows: "[...] respect for human dignity, freedom, democracy, equality, the rule of law and respect for human rights, including the rights of persons belonging to minorities. These values are common to the Member States in a society in which pluralism, non-discrimination, tolerance, justice, solidarity and equality between women and men prevail" (Eur-Lex 2012).

16 Moreover, EU membership requires "[...] the existence of a functioning market economy as well as the capacity to cope with competitive pressure and market forces within the Union. Membership presupposes the candidate's ability to take on the obligations of membership including adherence to the aims of political, economic and monetary union" (European Council 1993, p. 12).

17 Pickel, Gert. 2012. Deterioration of Democratic Quality. Comparative Analyses on their Cultural and Structural Conditions. unveröffentlichtes Manuskript.

18 Bulgaria and Romania joined the EU in 2007 but already signed the accession treaty in 2005. Therefore, they are included in the analysis just from the beginning. Croatia signed the accession treaty in December 2011 and joined the EU in 2013. Thus, Croatia is included in the analysis from 2011 to 2016.
} 
points in time, the years 2008, 2012 and 2016 are chosen based on data availability ${ }^{19}$. Moreover, the period of analysis includes the time span for which erosions in the quality of democracy are described (Puddington 2011).

\subsection{Operationalization: Loss of quality of democracy and decline of democracy}

According to Erdmann's (2011) definition a decline of democracy is present when the overall quality of democracy deteriorates as well as in one of the two central dimensions of democracy - freedom and equality — and in the dimension of control. If this condition is not met, that is, if there is no deterioration in the overall quality, the control dimension and in at least one of the two dimensions of freedom and equality, the development does not represent a decline of democracy but a loss of quality. The most commonly used indices to measure the level of democracy are Polity IV, Freedom House or V-Dem. Freedom House and Polity IV consistently rank the old and new EU member states in the upper end of their scale-with a few recent exceptions. Since the article only looks at democracies (EU member states) and changes in the quality of democracy are more nuanced here than in cases of regime changes, an index is required which allows to reveal different degrees of quality as well as minor violations of the principles of freedom, equality and control of power (Pickel 2012, p. 2) ${ }^{20}$. Moreover, the article draws on Merkel et al. 's (2003) definition of liberal democracy, more specifically the embedded democracy. The Democracy Barometer data (DB) meets all of these requirements: First, it is based on Merkel et al.'s theoretical framework - the basis of Bühlmann et al.'s (2008a) theoretical concept of the quality of democracy. Second, it is a macro-level index measuring and comparing subtle differences in the quality of established democracies (Engler et al. 2020). In addition, it "provides a highly differentiated set of components [...] and a number of variables and indicators for measuring democracy" (Erdmann 2011, p. 40).

The DB consists of 98 indicators which present the lowest level of the concept. These indicators are aggregated into 51 subcomponents, 18 components, 3 fundamental principles of democracy and finally the overall quality score. Unlike other indices, the DB takes into account both the "rules in law" and "rules in use" (Engler et al. 2020, p. 54). It is primarily based on objective aggregate data and not on subjective expert assessments (Bühlmann et al. 2012). ${ }^{21}$ Due to missing theoretical thresholds for a variety of indicators used by the $\mathrm{DB}$, the authors decide to standardise the indices by identifying the "best and worst practice in established democracies" (Merkel et al. 2014, p. 5). Since the 15 old EU member states are to be the benchmark for the analysis of the quality of democracy and the decline of

\footnotetext{
19 The Democracy Barometer is only available until 2017. The data gaps in 2017 are so large that it can only be used up to 2016.

${ }^{20}$ Pickel, Gert. 2012. Deterioration of Democratic Quality. Comparative Analyses on their Cultural and Structural Conditions. unveröffentlichtes Manuskript.

21 The DB uses sources as Freedom House (Merkel et al. 2014), which is based on expert assessments (Pickel and Pickel 2006). In this way the DB does not directly rely on expert assessments but still uses aggregate data which are based on experts.
} 
democracy in the 28 EU member states, the DB standardized by (Engler et al. 2020) cannot be used. Instead, an EU blueprint sample, consisting of 14 old EU member states from 1993 until 2003, is compiled on the basis of the raw data. ${ }^{22}$ The year 1993 is chosen as a starting point because it was the year the Copenhagen criteria were defined. The Copenhagen criteria reflect the democracy level of the old member states and were the benchmark to be achieved by acceding states. The period ends in 2003, as in 2004 Cyprus, Malta and eight of ten Central and Eastern European countries joined the EU. Based on the authors' approach (Merkel et al. 2014), all indicators in the blueprint sample are rescaled according to the best and worst practice, i.e. the lowest empirical value of each indicator in the blueprint sample is assigned 0 and the highest empirical value is assigned 100. Then, all EU member states from 2004 until 2016 are included in the dataset. Their values are rescaled in relation to the best and worst practice case of the EU blueprint sample. Thus, it can be analysed in detail how the EU member states perform and if only new EU member states or also old EU member states deviate from the EU-14 benchmark. By calculating the difference values between 2004 and 2008, 2008 and 2012 as well as 2012 and 2016, a loss of the overall quality of democracy or a decline of democracy in the EU members can be determined.

\section{Analysis}

Using the DB data a descriptive analysis is conducted to determine whether there has been a decline in democracy in the EU member states. In addition, I analyse which fundamental principles are most affected by deteriorations and if patterns exist.

\subsection{Loss of quality of democracy}

The descriptive analysis shows a somewhat worrying picture. The difference scores of the quality of democracy from 2004 to 2008 and 2008 to 2012 reveal that the number of EU member states which display a loss in their quality of democracy increases from 9 to 21 between the first two periods (Fig. 1). The number of countries with an improvement in their quality decreases by almost two thirds, from 18 to 6 states. Surprisingly, the old EU member states make up the majority of countries with negative difference values: In 2008, eight old (Denmark, Finland, Greece, Ireland, Italy, Netherlands, Spain, United Kingdom) and only one new member state (Estonia) belong to this group. In 2012, the number increases to 13 old (all old ones except Italy and United Kingdom) and eight new member states (Bulgaria, Cyprus, Estonia, Hungary, Malta, Romania, Slovakia, Slovenia). In contrast, the new member

\footnotetext{
22 The old EU member states are selected on the basis of Freedom House (value of 1.5 or lower) and Polity IV (value of 9 or above) in the same way as the DB selects its blueprint countries (Merkel et al. 2014). In 1993, Italy is excluded from the blueprint sample because Freedom House rates the country with the value 2. Greece is not included at all because Freedom House consistently rates it as 2 from 1993 to 2001 .
} 


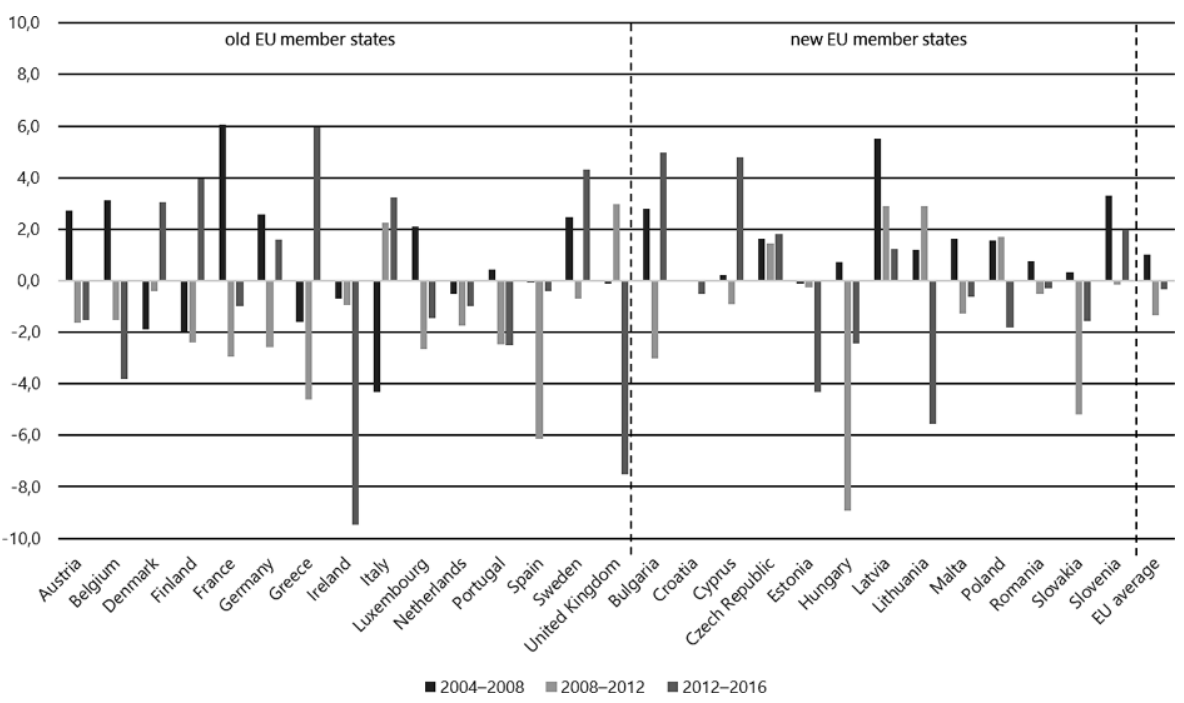

Fig. 1 Changes in the quality of democracy in the EU member states (difference values 2004 to 2008, 2008 to 2012 and 2012 to 2016). Source: Author's compilation based on DB data standardized with regard to EU member states

states outweigh the old ones in terms of positive difference values: In 2008, eleven new members and seven old ones can be assigned to the group. In 2012, there are four new members and only two old members in this group. Hungary and Spain are the countries most affected by a loss in the quality of democracy between 2008 and 2012. In Spain, this can be attributed largely to the deterioration of the function governmental capability. In Hungary, the functions competition, participation and individual freedoms have been restricted to a considerable degree (Smolka 2019, p. $365,379,385,391) .^{23}$

The number of countries showing a loss in the quality of their democracy is decreasing again between the second (2008-2012) and the third period (2012-2016) from 21 to 17 (Fig. 1). Again, there are more old member states with a negative difference score of the quality of democracy than new member states. However, the old and new member states almost equalize — nine old states (Austria, Belgium, France, Ireland, Luxembourg, the Netherlands, Portugal, Spain, United Kingdom) and eight new states (Croatia, Estonia, Hungary, Lithuania, Malta, Poland, Romania, Slovakia) show a loss in the quality of democracy. But in the third period, and for the first time, more old (six) than new (five) EU members show positive developments in their quality of democracy. Thus, a significantly more positive trend can be observed, although the number of member states with a loss in their quality of democracy is higher than in the first period (2004-2008: 10 vs. 2012-2016: 17). The comparison of the difference values also shows that only the Czech Republic and Latvia are able to improve their quality between the three time periods. Consistently negative

23 A detailed analysis of the functions and components that are key to the severe losses in the quality of democracy can be found in chapter 4.4. in Smolka (2019). 


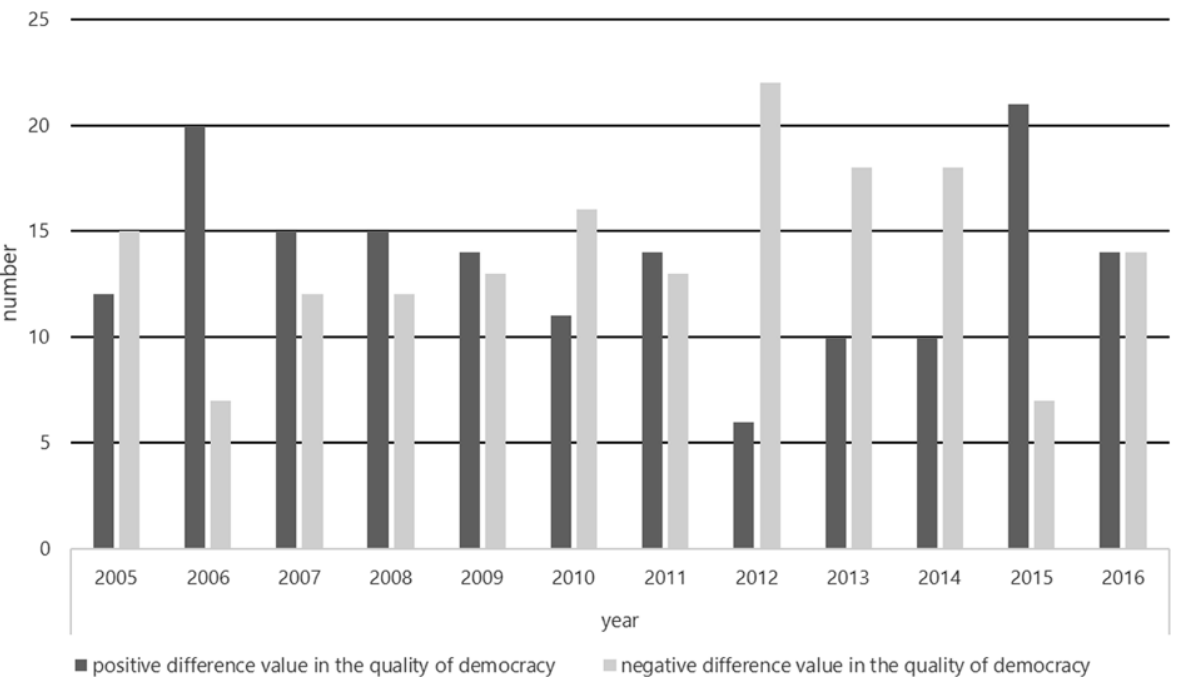

Fig. 2 Year-to-year changes in the quality of democracy in the EU member states. Source: Author's compilation based on DB data standardized with regard to EU member states

difference values can be found in Ireland, the Netherlands and Spain. Based on the heterogenous descriptive results, no pattern can be discerned with regard to the loss in the quality of democracy. This also applies to the countries that were severely affected by the Global Financial Crisis and European Sovereign Debt Crisis which falls into the second period of analysis: Greece, Ireland, Italy, Portugal, Spain, Cyprus, Hungary, Latvia, Romania, and Slovenia. In the second period, the loss in the quality of democracy varies greatly among these countries (e.g. Spain, Slovenia). Italy and Latvia can even improve their quality. In contrast, in EU members such as Germany or Slovakia, which were not as badly affected by the crisis, the quality of democracy deteriorated. The two countries most affected by a loss in the quality of democracy between 2012 and 2016 were Ireland and the United Kingdom. In Ireland, this can be attributed largely to the deterioration of the functions public sphere and rule of law. In the United Kingdom, the functions individual liberties and governmental capability have deteriorated significantly. However, it is important to note that the starting level of the quality of democracy of the old member states was significantly higher than that of the new member states. Thus, the EU should not only keep an eye on the quality of democracy in its new member states, but also on that of its old members.

A closer look at the year-to-year changes in the quality of democracy shows that in almost half of the years (five out of 12) the negative developments outweigh the positive ones (Fig. 2). Most of the negative changes occurred between the years 2010 (16) and 2016 (14). In the years 2012 to 2014, more than two thirds of the EU members showed a loss in quality. 


\subsection{Decline of democracy}

To determine whether the losses in the quality of democracy also represent a decline of democracy, the three basic democratic principles and the overall quality have to be analysed (Erdmann 2011, p. 24).

In the first period (2004-2008), only five out of nine member states, showing a loss in their quality, can be assigned to the group with a decline of democracy (Table 1). These countries reveal a loss of their overall democratic quality as well as deteriorations in the principles of freedom and/or equality, and in the principle of control. Within this group, Denmark, Finland, and Italy reduce their overall quality

Table 1 Difference values of the overall quality of democracy, and the three democratic principles freedom, equality, and control (2004 to 2008)

\begin{tabular}{|c|c|c|c|c|c|}
\hline $\begin{array}{l}\text { EU } \\
\text { members }\end{array}$ & $\begin{array}{l}\text { Difference value } \\
\text { overall quality }\end{array}$ & $\begin{array}{l}\text { Difference } \\
\text { value freedom }\end{array}$ & $\begin{array}{l}\text { Difference } \\
\text { value equality }\end{array}$ & $\begin{array}{l}\text { Difference } \\
\text { value control }\end{array}$ & $\begin{array}{l}\text { Decline of } \\
\text { Democracy }\end{array}$ \\
\hline Denmark & -1.9 & -2.9 & -0.6 & -2.3 & 1 \\
\hline Estonia & -0.1 & 4.2 & -0.8 & -3.7 & 1 \\
\hline Finland & -2.0 & -0.2 & -2.9 & -2.8 & 1 \\
\hline Ireland & -0.7 & -2.9 & 3.5 & -2.7 & 1 \\
\hline Italy & -4.3 & -9.8 & -1.7 & -1.4 & 1 \\
\hline Austria & 2.7 & 3.0 & -0.1 & 5.3 & 0 \\
\hline Belgium & 3.1 & 13.7 & -7.2 & 2.9 & 0 \\
\hline Bulgaria & 2.8 & 2.5 & -2.0 & 7.9 & 0 \\
\hline Cyprus & 0.2 & -0.1 & 2.3 & -1.6 & 0 \\
\hline $\begin{array}{l}\text { Czech } \\
\text { Republic }\end{array}$ & 1.6 & -2.0 & 5.9 & 1.0 & 0 \\
\hline France & 6.1 & 5.5 & 3.6 & 9.0 & 0 \\
\hline Germany & 2.6 & 3.3 & 4.4 & -0.02 & 0 \\
\hline Greece & -1.6 & -7.1 & 0.6 & 1.7 & 0 \\
\hline Hungary & 0.7 & -0.8 & 0.2 & 2.7 & 0 \\
\hline Latvia & 5.5 & -1.1 & 3.1 & 14.5 & 0 \\
\hline Lithuania & 1.2 & 1.9 & -5.5 & 7.4 & 0 \\
\hline Luxembourg & 2.1 & -1.9 & 7.1 & 0.9 & 0 \\
\hline Malta & 1.6 & -1.2 & 2.8 & 3.1 & 0 \\
\hline Netherlands & -0.5 & 0.1 & 1.5 & -3.0 & 0 \\
\hline Poland & 1.5 & 2.3 & 1.6 & 0.7 & 0 \\
\hline Portugal & 0.4 & -2.1 & 1.1 & 2.2 & 0 \\
\hline Romania & 0,8 & 0.5 & 0.3 & 1.4 & 0 \\
\hline Slovakia & 0.3 & -1.0 & 2.0 & -0.02 & 0 \\
\hline Slovenia & 3.3 & -0.2 & -0.6 & 10.6 & 0 \\
\hline Spain & -0.1 & -2.2 & -0.5 & 2.6 & 0 \\
\hline Sweden & 2.5 & 0.5 & -1.6 & 8.4 & 0 \\
\hline $\begin{array}{l}\text { United } \\
\text { Kingdom }\end{array}$ & -0.1 & -0.9 & -2.8 & 3.3 & 0 \\
\hline
\end{tabular}

Source: Author's compilation based on DB data standardized with regard to EU member states Notes: in the column decline of democracy the value 1 is assigned if a decline of democracy according to the definition is present, the value 0 is assigned if the assumptions of the definition are not fulfilled 
and all three basic principles. Estonia decreases the areas of equality and control, Ireland the areas of freedom and control. Accordingly, the principle of freedom and equality are equally affected by deterioration in countries where a decline of democracy is present. Although five countries do not belong to the group with a decline of democracy, they must be considered as being at risk: Greece, the Netherlands, Spain and the United Kingdom, on the one hand, reduce their overall quality as well as either the principle of equality, freedom or control. Cyprus on the other hand, worsens the principle of control and freedom but not the overall quality. In total, 16 of the 27 countries worsen the area of freedom, twelve the area of equality and eight in the area of control. On a positive note, however, France, Poland and Romania can improve both their overall quality and the three fundamental principles.

A closer look at the old and new member states shows that in 2008 there are four old member states and only one new member state with a decline of democracy. Moreover, only old EU members (Denmark, Finland, Italy) deteriorate all three principles. Therefore, in the first period the first assumption is disconfirmed. Instead, the opposite is the case: Democratic dismantling in form of a decline of democracy is much more common in the old EU member states than in the new ones. However, the second hypothesis is confirmed: In nearly two thirds of the member states freedoms are threatened. It is by far the democratic principle most affected.

From 2008 to 2012, the number of countries showing a loss in their overall quality more than doubles from nine to 21 member states. 13 countries can be assigned to the group of countries with a decline of democracy (Table 2). This is an increase of $86 \%$ between the two periods. Within the group of countries showing a decline, Austria, Greece, Hungary, Slovakia, and Spain reduce not only their overall quality but also the level of all three principles. Bulgaria, Cyprus, Estonia, France, Germany, Ireland, and Portugal only worsen the principle of control and freedom while improving the equality. The only country with a decline of democracy that worsens equality but improves freedom is Romania. The remaining eight countries with losses in their overall quality show deteriorations in the principle of freedom (Belgium, Finland, the Netherlands, Sweden), freedom and equality (Denmark, Malta) or control (Slovenia). The countries have thus narrowly missed the deterioration in form of a decline of democracy. Again, the principle of freedom (20) is more often affected by deteriorations than the principle of control (16) and equality (9). In 2012, only two member states-Poland and the United Kingdom-are able to improve their overall quality and all three principles.

A comparison of the old and new member states shows that in 2012 seven old EU member states - although not exactly the same as in 2008-belong to the group of states experiencing a decline of democracy. The number of new member states, however, increases from one in 2008 to six in 2012. Estonia and Ireland show a decline of democracy in both periods. The decline occurs in old member states slightly more often than in the new member states. Besides, deteriorations in all three principles occur in five countries, namely in the three old EU members Austria, Greece, and Spain as well as in the two new members Hungary and Slovakia. Thus, the first assumption must be rejected, although the number of old and new member states with a decline of democracy converges. Again, the second assumption holds true-the principle most affected by deteriorations is freedom, followed by control. 
Table 2 Difference values of the overall quality of democracy, and the three democratic principles freedom, equality, and control (2008 to 2012)

\begin{tabular}{|c|c|c|c|c|c|}
\hline $\begin{array}{l}\text { EU } \\
\text { members }\end{array}$ & $\begin{array}{l}\text { Difference value } \\
\text { overall quality }\end{array}$ & $\begin{array}{l}\text { Difference } \\
\text { value freedom }\end{array}$ & $\begin{array}{l}\text { Difference } \\
\text { value equality }\end{array}$ & $\begin{array}{l}\text { Difference } \\
\text { value control }\end{array}$ & $\begin{array}{l}\text { Decline of } \\
\text { Democracy }\end{array}$ \\
\hline Austria & -1.6 & -0.8 & -2.9 & -1.2 & 1 \\
\hline Bulgaria & -3.0 & -1.5 & 3.4 & -11.0 & 1 \\
\hline Cyprus & -0.9 & -14.1 & 11.6 & -0.7 & 1 \\
\hline Estonia & -0.3 & -7.6 & 10.0 & -3.2 & 1 \\
\hline France & -2.9 & -9.4 & 1.7 & -1.0 & 1 \\
\hline Germany & -2.6 & -6.3 & 0.3 & -1.7 & 1 \\
\hline Greece & -4.6 & -6.8 & -2.7 & -4.3 & 1 \\
\hline Hungary & -8.9 & -10.0 & -6.6 & -10.2 & 1 \\
\hline Ireland & -0.9 & -4.1 & 1.5 & -0.2 & 1 \\
\hline Portugal & -2.5 & -8.9 & 1.7 & -0.2 & 1 \\
\hline Romania & -0.5 & 1.1 & -1.2 & -1.5 & 1 \\
\hline Slovakia & -5.2 & -4.4 & -1.7 & -9.5 & 1 \\
\hline Spain & -6.1 & -6.8 & -0.4 & -11.1 & 1 \\
\hline Belgium & -1.5 & -9.7 & 2.7 & -2.4 & 0 \\
\hline $\begin{array}{l}\text { Czech } \\
\text { Republic }\end{array}$ & 1.5 & 3.1 & -1.3 & 2.6 & 0 \\
\hline Denmark & -0.4 & -4.1 & -0.4 & 3.2 & 0 \\
\hline Finland & -2.4 & -11.6 & 0.8 & 3.5 & 0 \\
\hline Italy & 2.2 & 4.8 & 2.0 & -0.2 & 0 \\
\hline Latvia & 2.9 & 6.4 & 6.5 & -4.2 & 0 \\
\hline Lithuania & 2.9 & -2.2 & 8.1 & 2.9 & 0 \\
\hline Luxembourg & -2.6 & -9.7 & 0.7 & 0.7 & 0 \\
\hline Malta & -1.3 & -4.0 & 0.0 & 0.2 & 0 \\
\hline Netherlands & -1.7 & -7.8 & 0.9 & 1.5 & 0 \\
\hline Poland & 1.7 & 0.9 & 2.3 & 1.9 & 0 \\
\hline Slovenia & -0.2 & 0.2 & 0.6 & -1.3 & 0 \\
\hline Sweden & -0.7 & -7.0 & 2.1 & 2.7 & 0 \\
\hline $\begin{array}{l}\text { United } \\
\text { Kingdom }\end{array}$ & 3.0 & 3.3 & 2.4 & 3.3 & 0 \\
\hline
\end{tabular}

Source: Author's compilation based on DB data standardized with regard to EU member states Notes: in the column decline of democracy the value 1 is assigned if a decline of democracy according to the definition is present, the value 0 is assigned if the assumptions of the definition are not fulfilled

In 2016, only eight out of 17 member states showing a loss of their overall quality can be assigned to the group with a decline of democracy (Table 3). Thus, the number of EU member states with a decline of democracy decreases again between the second and third period. The results show that only the three countries Hungary, Ireland and Lithuania simultaneously reduce their levels of freedom, equality, and control. Belgium, Poland, Slovakia, and the United Kingdom worsen their level of freedom while improving their level of equality. Estonia shows the contrasting development-improvement of freedom and deterioration of equality. In 2016, nine countries must be classified as jeopardized: Croatia, Luxemburg, and Portugal decrease their overall quality as well as freedom and equality, Malta and 
Table 3 Difference values of the overall quality of democracy, and the three democratic principles freedom, equality and control (2012 to 2016)

\begin{tabular}{|c|c|c|c|c|c|}
\hline $\begin{array}{l}\text { EU } \\
\text { members }\end{array}$ & $\begin{array}{l}\text { Difference value } \\
\text { overall quality }\end{array}$ & $\begin{array}{l}\text { Difference } \\
\text { value freedom }\end{array}$ & $\begin{array}{l}\text { Difference } \\
\text { value equality }\end{array}$ & $\begin{array}{l}\text { Difference } \\
\text { value control }\end{array}$ & $\begin{array}{l}\text { Decline of } \\
\text { Democracy }\end{array}$ \\
\hline Belgium & -3.8 & 8.1 & 5.0 & -6.9 & 1 \\
\hline Estonia & -4.3 & 11.1 & 8.4 & -1.9 & 1 \\
\hline Hungary & -2.4 & -6.9 & 8.1 & -1.8 & 1 \\
\hline Ireland & -9.5 & -3.5 & 1.1 & -17.5 & 1 \\
\hline Lithuania & -5.5 & 7.8 & 8.1 & -5.7 & 1 \\
\hline Poland & -1.8 & -6.6 & -4.3 & -2.9 & 1 \\
\hline Slovakia & -1.6 & -10.6 & 2.3 & -5.9 & 1 \\
\hline $\begin{array}{l}\text { United } \\
\text { Kingdom }\end{array}$ & -7.5 & -3.8 & 1.9 & -20.2 & 1 \\
\hline Austria & -1.5 & -8.4 & 2.9 & 1.0 & 0 \\
\hline Bulgaria & 5.0 & -4.2 & 9.4 & 1.8 & 0 \\
\hline Croatia & -0.5 & -4.7 & -3.5 & 6.9 & 0 \\
\hline Cyprus & 4.8 & 5.7 & -16.4 & 9.3 & 0 \\
\hline $\begin{array}{l}\text { Czech } \\
\text { Republic }\end{array}$ & 1.8 & -7.8 & 2.3 & -0.2 & 0 \\
\hline Denmark & 3.0 & 2.4 & 5.2 & -7.0 & 0 \\
\hline Finland & 4.0 & -4.2 & -1.2 & 1.5 & 0 \\
\hline France & -1.0 & -7.0 & -3.6 & 2.8 & 0 \\
\hline Germany & 1.6 & -10.2 & -0.4 & -2.8 & 0 \\
\hline Greece & 5.9 & 3.9 & 2.9 & -1.6 & 0 \\
\hline Italy & 3.2 & -4.7 & 0.1 & -0.6 & 0 \\
\hline Latvia & 1.2 & -1.9 & 7.6 & 0.6 & 0 \\
\hline Luxembourg & -1.5 & 8.8 & 1.8 & 5.2 & 0 \\
\hline Malta & -0.6 & -1.1 & 11.5 & -17.3 & 0 \\
\hline Netherlands & -1.0 & 3.9 & -0.8 & 5.8 & 0 \\
\hline Portugal & -2.5 & -7.8 & -1.6 & 3.2 & 0 \\
\hline Romania & -0.3 & 4.1 & 11.6 & -7.5 & 0 \\
\hline Slovenia & 2.0 & -2.7 & 0.2 & 8.1 & 0 \\
\hline Spain & -0.4 & 3.6 & -5.8 & 1.2 & 0 \\
\hline Sweden & 4.3 & 0.6 & 8.6 & 3.6 & 0 \\
\hline
\end{tabular}

Source: Author's compilation based on DB data standardized with regard to EU member states Notes: in the column decline of democracy the value 1 is assigned if a decline of democracy according to the definition is present, the value 0 is assigned if the assumptions of the definition are not fulfilled

Romania worsen their overall quality and control. Austria, France, the Netherlands, and Spain reduce their overall quality and freedom. Once again, the principle of freedom is most frequently affected by deteriorations (17), followed by the principle of control (15) and equality (9). This time, there are again three countries (Bulgaria, Finland, Sweden) that can improve their level in all three dimensions.

In 2016, for the first time in the period under review, more new than old EU member states show a decline of democracy. Now five new and four old EU members display this development. Thus, the first assumption has to be confirmed. Again, 


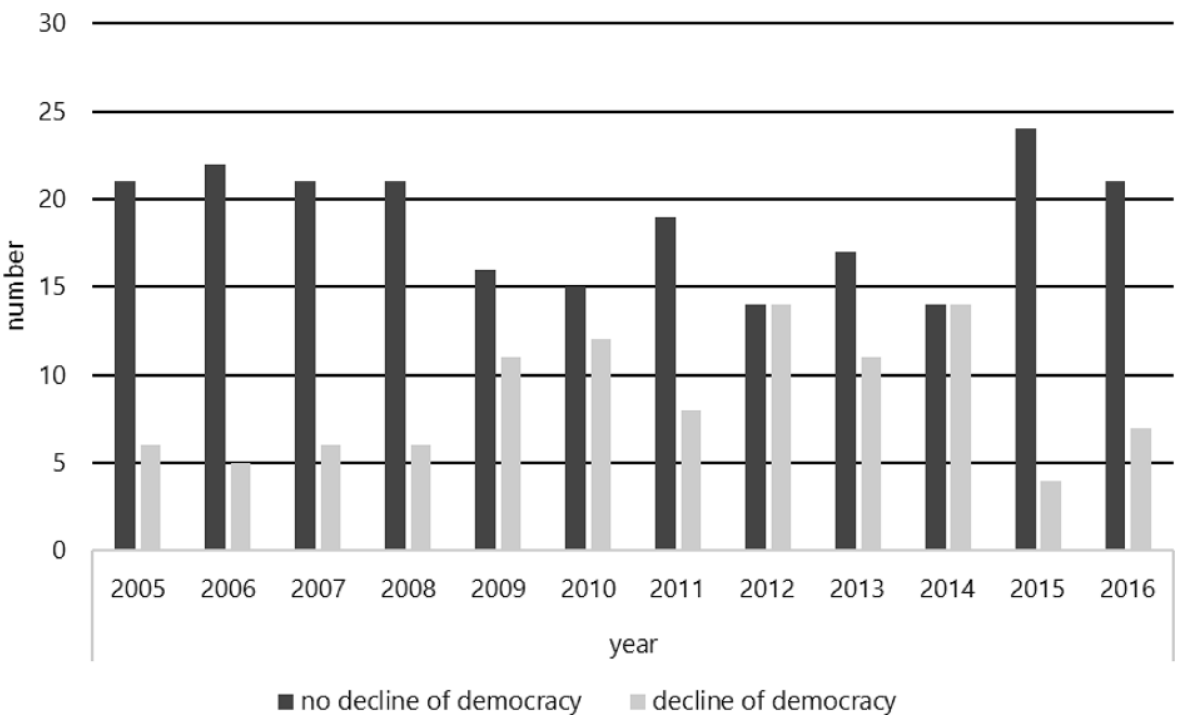

Fig. 3 Yearly presence of a decline of democracy in the EU member states. Source: Author's compilation based on DB data standardized with regard to EU member states

the second assumption is supported by the empirical findings. The principle of freedom (17) deteriorates more often than control (15) and equality (9).

If all three analysis periods are considered, it becomes apparent that only two EU member states consistently show a decline of democracy: Estonia and Ireland. Two countries show a decline of democracy at two points in time each-Hungary and Slovakia in 2008 and 2016. Here, the new member states outnumber the old members. But over the entire period of analysis, more old members than new members have experienced a decline of democracy at least once: Twelve old member states (all except Luxembourg, the Netherlands, and Sweden) and eight new member states (all except Croatia, Czech Republic, Latvia, Malta, Slovenia). Although the decline of democracy occurs in the new EU members more frequently in series and must thus be considered somewhat more permanent, the numerous declines in democracy in the old member states should not be neglected either.

A detailed analysis of the individual years 2005-2016 (Fig. 3) shows that serious deteriorations in the form of a decline of democracy occurred less frequently: At no time the number of member states with a decline of democracy exceed the number of member states without a decline of democracy. But in 2012 and 2014 the number of member states with a decline of democracy is the same as the number without a decline of democracy. Nevertheless, each year at least four countries had to be assigned to the group of countries showing a decline of democracy. Therefore, the control dimension respectively the rule of law has been under severe pressure in the EU member states for some time now. 


\section{The role of the $\mathrm{EU}$}

The descriptive analysis has shown that neither the loss of quality nor the decline of democracy can be considered a rare phenomenon in the EU member states. On the contrary, the EU has been confronted with these negative changes in old and new member states for quite some time now. These developments exists even though the EU ties its membership to the fulfilment of democratic and constitutional conditions, namely the Copenhagen criteria (Kneuer 2007). A high quality of democracy and the prevention of a decline of democracy in its member states should be of great importance for the EU, since the EU can only be as democratic as its members are. Thus, the question arises as to why the EU is unable to counter these developments.

So far, the EU is only able to positively influence the democratic development of candidate countries - as the democratization and consolidation of the young democracies of the third wave of democratization shows (Kneuer 2007). However, the positive influence of the EU's accession conditionality seems to fizzle out after accession (Ganev 2013). Empirical studies support this assumption by showing, that the EU is unable to prevent deteriorations in key dimensions of liberal democracy such as the rule of law or freedom of the press after accession (Bochsler and Juon 2020; Ganev 2013; Kelemen 2017; Smolka 2019). Looking explicitly at 19 democracies in Central and Eastern Europe, Bochsler and Juon (2020, p. 179) point out that "EU membership itself is not systematically associated with improvements of the quality of democracy". At the same time, however, EU membership itself cannot be equated with deteriorations in the quality of democracy. The authors find no postaccession development patterns in Central and Eastern Europe. In this regard EU member states' paths "are very heterogenous" (Bochsler and Juon 2020, p. 180). This conclusion, i.e. the heterogeneous positive and negative developments in the quality of democracy, applies not only to the new member states, but also to the old member states. Surprisingly, they represent the majority of countries affected by a decline of democracy (see also Smolka 2019). Moreover, empirical analyses (regression analysis, Qualitative Comparative Analysis) show that neither differentiated integration, i.e. different forms of integration and enhanced cooperation between member states such as the European Monetary Union (Leuffen et al. 2013), nor Europeanization, i.e. repercussions of the European integration on the member states (Axt et al. 2007), can be considered as factors which prevent a decline of democracy in EU member states (Smolka 2019

The EU not only lacks a comprehensive instrument for monitoring basic democratic values in its member states and preventing deteriorations in the quality of democracy, but also, to some extent, the political will. In the European Parliament (EP), for example, belonging to a strong party family such as the European People's Party (EPP) can avoid sanctions against difficult group members showing illiberal tendencies such as the Fidész Party (Müller 2013). In both the last and current legislative periods, Fidész is helping the EPP to maintain its lead (182 seats, 12 from Fidész) over the second largest party in the EP, the social democratic S\&D group (154 seats). Despite provocations involving Jean-Claude Juncker, George Soros and conspiracy theory in the EP election campaign 2019 and calls for the expulsion of the Fidész party from the EPP, Manfred Weber and other EPP leaders rejected 
it. Instead, the EPP as a party suspended Fidesz, but not the parliamentary group, whose rules of procedure did not provide for such an instrument. Thus, the 12 seats of Fidész still counted to the EPP group and helped to confirm Ursula von der Leyen as President of the Commission. In January 2020 a committee of EPP "wise men" recommended to extent the suspension indefinitely, which EPP chairman Donald Tusk followed (Kelemen 2020; Ziemer 2020). On March 3, 2021, the EPP changed its rules of procedure so that Fidész MEPs can now be suspended. To avoid an official suspension by the EPP, Orbán announced the resignation of the Fidész MEPs on the same day. While in the case of Poland (PiS belongs to the European Conservatives and Reformists Party) the new EU Rule of Law Framework was very quickly applied in January 2016 and the European Commission asked the Council to activate Article 7 (1) TEU in December 2017, Hungary was able to bypass this dialogue procedure, despite strong criticism from EU institutions and member states. It only came under pressure in 2018 when the EP followed the initiative of Green MEP Sargentini and, with a two-thirds majority, called on the Council to use the preventive mechanism of Article 7 (1) TEU against Hungary. This time, even EPP members supported the initiative (Smolka 2019).

In addition, instruments such as Article 7 TEU are politically hard to activate, as they require a unanimous decision in the European Council. To circumvent the activation of Article 7 procedures and the resulting sanctions, like-minded countries may establish informal relations with each other. By using their veto power, autocratically inclined countries can thus protect each other. The mutual support of Fidész and PiS is a case in point. Alternatively, the Council can at least set in motion the preventive mechanism of Article 7(1) TEU, since its activation requires only a fourfifths majority. In the case of Hungary and Poland hearings and a detailed report by the Commission on the situation in Hungary and Poland led to the decision on September 22, 2020, that the conditions for ending the Article 7 proceedings were not met and that the proceedings would continue. Nevertheless, it is unlikely that the Council can even reach a four-fifths majority as Central and Eastern European countries are critical of the process. However, the political will to act is not always given in the European Council, and also in the European Commission (Kelemen 2020, pp. 489-490; Smolka 2019, p. 511). Even though the Commission is supposed to assess developments of democracy and rule of law in an unbiased manner and, if necessary, to trigger the Rule of Law Framework or the preventive mechanism of Article 7 TEU, "partisan considerations also play a role in the decision making of that body and in the preferences of particular Commissioners" (Lang 2017, p. 27).

Well aware that its current instruments are rather toothless and inadequate to combat a decline of democracy in its member states, the European Commission proposed a new financial condition in May 2018 that would allow the suspension of EU funds in cases of systemic rule of law violations (Blauberger and van Hüllen 2021, p. 1). After the European Council, the European Parliament adopted on December 16, 2020 , the compromise of the "Regulation on a general regime of conditionality for the protection of the Union budget." A first compromise was blocked by Hungary and Poland (Scheppele et al. 2020). Such an instrument is urgently needed, as the "EU funds have helped prop up authoritarian member government in Hungary" (Kelemen 2020, p. 490) and Poland. In the last budget period (2014-2020), Poland and Hun- 
gary were the largest recipients of the European Structural and Investment Funds. In Hungary, the EU co-financed 95 per cent of all public investments in recent years (Kelemen 2020, p. 490; Keszthelyi 2017). But research showed that "a significant portion of the EU funding allocated to Hungary has been channelled by the Orbán government into the pockets of Fidész cronies" (Kelemen 2020, p. 490); (Vachudova 2020, pp. 329-331). Hungary was therefore described as a "post-communist mafia state" by former Education Minister Bálint Magyar (2019). Nevertheless, Hungary and Poland were allowed to opt-out of participating in the European Public Persecutor's Office. Thus, the EU is unable to investigate crimes against the EU budget such as fraud or corruption in both countries (European Commission 2020). The entry into force of the rule of law mechanism on January 1, 2021, was therefore all the more important. Yet, its purpose is not to combat violations of the rule of law in general, but to protect the EU's financial interests against any kind of fraud, corruption and conflict of interest (Zwaan 2020). However, not only the future effectiveness of the mechanism is questioned, but also its' application from January 1, 2021. The conclusions of the European Council (2020) provide for a delay in the application of the regulation, stating that the regulation shall not be brought into force before the European Court of Justice (ECJ) has given a ruling on its legality and "not before a complex consultation process with the member states produces 'guidelines' that will make clear how the mechanism will be used" (Scheppele et al. 2020). Although the conclusions are not legally binding (Alemanno and Chamon 2020), the Commission and EP are unlikely to override them. As announced, Poland and Hungary filed an action with the ECJ on March 11, 2021. Poland and Hungary see the regulation as a new procedure not provided for in the EU treaties and beyond control. In this way, they are preventing the mechanism from being applied for the foreseeable future. With regard to the effectiveness of the regulation, an in-depth analysis of the draft, which also holds true for the adopted version, concludes that the regulation "would indeed improve the speed and likelihood of sanctions compared to existing mechanisms, but lacks in the determinacy of conditions and procedures, thus undermining its perceived legitimacy and chances of success" (Blauberger and van Hüllen 2021, p. 1). Since the text of the regulation leaves a lot of room for interpretation, it can evolve into a pure anti-corruption measure or into a genuine rule of law mechanism (Jakab and Kirchmair 2020) and thus a much needed shield against the decline of democracy in the EU member states. But this, too-like the design and application of the already existing instruments ${ }^{24}$ - depends on the political will of the European Commission, the European Council and the European Parliament to act (Smolka 2019).

\section{Conclusion: The EU still lacks the political will to act}

Against the background of current developments in some EU member states such as Hungary, Poland, Slovenia or the Czech Republic, the debate on the quality of

\footnotetext{
${ }^{24}$ For a detailed overview of existing tools as well as considerations from academia, see Smolka (2019, p. 53).
} 
democracy and the decline of democracy continues to be highly relevant. Nevertheless, a systematic comparative analysis of a decline of democracy in the $28 \mathrm{EU}$ member states, based on a sound theoretical concept and an index allowing a finegrained analysis of the quality of democracy, is still missing. This article addresses these shortcomings by shedding light on the discussion about losses of quality and declines of democracy in two ways: First, a comprehensive theoretical basis is presented that allows to distinguish between the two concepts and to derive criteria for empirical analyses. For this purpose, I draw on the concept of liberal democracy by Merkel (2004), the concept of the quality of democracy by Bühlmann et al. (2008a) based on it, and Erdmann's (2011) definition of the decline of democracy. Second, using the criteria, an empirical analysis of the state of democracy-namely the presence of losses of the quality of democracy and declines of democracy-in all EU member states between 2004 and 2016 is conducted. The analysis relies on the data of the Democracy Barometer, which was standardized with regard to the EU member states. In addition, the role of the EU and its possibilities for intervention in relation to these developments, e.g. Article 7 TEU, the "Rule of Law Framework" and the "Regulation on a general regime of conditionality for the protection of the Union budget" are discussed.

The results of the analysis paint a mixed, but rather gloomy picture: Apart from the first period of analysis (2004-2008), the majority of EU member states showed a loss in the quality of their democracy. Between 2004 and 2008 "only" nine countries recorded a loss in the quality of democracy, with five of the nine countries showing a decline of democracy. In the second period of analysis (2008-2012), the number of member states with a loss in the quality and a decline of democracy more than doubled: 21 states - and thus two-thirds of all EU member states-displayed a loss, and 13 countries even met the strict criteria for a decline of democracy. The picture improves somewhat in the last analysis period (2012-2016): The number of countries with a loss in the quality of democracy drops to 17 , and the number of member states with a decline of democracy decreases to eight. In the first two analysis periods, more old than new member states show a loss in the quality and a decline of democracy. In the third analysis period the picture turns: Now, slightly more new than old member states register a decline of democracy. It is worrying, however, that Estonia and Ireland show a continuous decline in democracy. It is also alarming that the two most powerful EU states and EU founding members, France, and Germany, have shown a decline of democracy in the second analysis period. This, somehow, limits their ability to push for sanctions in the European Council-given that they do not even themselves comply with the standards they demand of others. Moreover, the results show that the democratic principle of freedom is more frequently affected by deterioration than the principles of equality and control. Overall, neither a pattern nor a general de-democratization trend or even a third reverse wave can be discerned from the results. Yet, the results should give cause for concern.

To counteract these negative developments, possible causes need to be looked at. A large number of explanatory mechanisms can now be found in the literature. These include for instance the rise of (ethno)populist parties and party leaders (Bochsler and Juon 2020; Vachudova 2020; Ziemer 2020, p. 258), the emigration of dissatisfied citizens as well as a weakened civil society and opposition (Kelemen 2020). In 
contrast, modernization theory, political culture, and differentiated integration and Europeanization can not fully explain the occurrence of the decline in democracy (Smolka 2019).

Illiberal democracy seems to be the new variety of authoritarianism that Huntington pointed out more than two decades ago. What makes this variant dangerous is the fact that it arises within the cloak of democracy (Krastev 2018). For the EU, the quality of democracy in its member states should be extremely important, because "[w]ithout stable and functioning democracies in member states, the EU would certainly have to redefine its self-image of being a community of values, of which democracy and rule of law are key principles [...]" (Lang 2017, p. 13). Moreover, a high quality of democracy and the absence of declines of democracy in the member states should be of central interest to the EU, since the EU can only be as democratic as its member states. Thus, it is necessary to qualify the EU's role as guardian of the democratic fundamental values. Time will show if - at least- the newly adopted "Regulation on a general regime of conditionality for the protection of the Union budget" will be effective in protecting the rule of law and stop the funding of authoritarian governments in their own ranks (Blauberger and van Hüllen 2021; Kelemen 2020; Scheppele et al. 2020). There is a need for further research and recommendations for action on how to make the façade crumble and reveal the "ugly" face of mild autocratic regimes, for instance how "mafia-state structures" can be broken up, the independence and diversity of media can be reinstalled and a strong civil society and opposition can be re-activated. Now, the EU is at a crossroad: appeasement with autocrats or defence of fundamental democratic values. For the EU to emerge victorious from the current severe challenge, not only powerful tools need to be developed. It is much more important that the political will to act is established in all EU institutions. There is an urgent need for action.

Funding Open Access funding enabled and organized by Projekt DEAL.

Open Access This article is licensed under a Creative Commons Attribution 4.0 International License, which permits use, sharing, adaptation, distribution and reproduction in any medium or format, as long as you give appropriate credit to the original author(s) and the source, provide a link to the Creative Commons licence, and indicate if changes were made. The images or other third party material in this article are included in the article's Creative Commons licence, unless indicated otherwise in a credit line to the material. If material is not included in the article's Creative Commons licence and your intended use is not permitted by statutory regulation or exceeds the permitted use, you will need to obtain permission directly from the copyright holder. To view a copy of this licence, visit http://creativecommons.org/licenses/by/4. $0 /$.

\section{References}

Ágh, Attila. 2016. The Decline of Democracy in East-Central Europe. Hungary as the Worst-Case Scenario. Problems of Post-Communism 63(5-6):277-287.

Alemanno, Alberto, and Merijn Chamon. 2020. To save the rule of law you must apparently break it. https:// verfassungsblog.de/to-save-the-rule-of-law-you-must-apparently-break-it/. Accessed 11 Mar 2021.

Andersen, Jørgen G. 2006. Political power and democracy in Denmark: decline of democracy or change in democracy? Journal of European Public Policy 13(4):569-586. https://doi.org/10.1080/ 13501760600693937.

Axt, Heinz-Jürgen, Antonio Milososki, and Oliver Schwarz. 2007. Europäisierung - ein weites Feld. Literaturbericht und Forschungsfragen. Politische Vierteljahresschrift 48(1):136-149. http://link.springer. com/content/pdf/10.1007\%2Fs11615-007-0011-z.pdf. Accessed 04.04.16. 
Blauberger, Michael, and Vera van Hüllen. 2021. Conditionality of EU funds: an instrument to enforce EU fundamental values? Journal of European Integration 43(1):1-16. https://www.tandfonline.com/doi/ full/10.1080/07036337.2019.1708337. Accessed 11.03.21.

Bochsler, Daniel, and Andreas Juon. 2020. Authoritarian footprints in Central and Eastern Europe. East European Politics 36(2):167-187.

Bühlmann, Marc, Wolfgang Merkel, Bernhard Weßels, and Lisa Müller. 2007. The quality of democracy: democracy barometer for established democracies. Zurich, Berlin: NCCR Democracy, University of Zurich, Social Science Research Centre Berlin (WZB).

Bühlmann, Marc, Wolfgang Merkel, and Bernhard Weßels. 2008a. The quality of democracy: democracy barometer for established democracies: working paper no. 10a. http://www.nccr-democracy.uzh.ch/ publications/workingpaper/pdf/WP10a.pdf. Accessed 2 Mar 2016.

Bühlmann, Marc, Wolfgang Merkel, Lisa Müller, and Bernhard Weßels. 2008b. Wie lässt sich Demokratie am besten messen? Zum Forumsbeitrag von Thomas Müller und Susanne Pickel. Politische Vierteljahresschrift 49(1):114-122. http://download.springer.com/static/pdf/189/art\%253A10.1007 \%252Fs11615-008-0089-y.pdf?auth66=1410182715_68558104a41735c02efad2bc22f34daa\&ext=. pdf. Accessed 06.09.14.

Bühlmann, Marc, Wolfgang Merkel, Lisa Müller, and Bernhard Weßels. 2012. The democracy barometer: a new instrument to measure the quality of democracy and its potential for comparative research. $E u$ ropean Political Science 11(4):519-536. http://www.palgrave-journals.com/eps/journal/v11/n4/pdf/ eps201146a.pdf. Accessed 22.01.15.

Dahl, Robert A. 1971. Polyarchy: participation and opposition. New Haven: Yale University Press.

de Zwaan, Jaap. 2020. The European Union and the rule of law: a new instrument. https://www.nhc.nl/theeuropean-union-and-the-rule-of-law-a-new-instrument/. Accessed 11 Mar 2021.

Diamond, Larry J. 1999. Developing democracy. Toward consolidation. Baltimore: Johns Hopkins University Press.

Diamond, Larry J. 2008. The democratic rollback. The resurgence of the predatory state. Foreign Affairs 87(2):36-48.

Diamond, Larry J. 2015. Facing up to the democratic recession. Journal of Democracy 26(1):141-155. http://muse.jhu.edu/journals/journal_of_democracy/v026/26.1.diamond.pdf. Accessed 30.01.15.

Diamond, Larry J., and Leonardo Morlino (eds.). 2005. Assessing the quality of democracy. Baltimore: Johns Hopkins University Press.

Engler, Sarah, Lucas Leemann, Tarik Abou-Chadi, Heiko Giebler, Karima Bousbah, Daniel Bochsler, Marc Bühlmann, Miriam Hänni, Lea Heyne, Andreas Juon, Wolfgang Merkel, Lisa Müller, Saskia Ruth, and Berhard Wessels. 2020. Democracy barometer. Codebook. Version 7. https:// democracybarometerorg.files.wordpress.com/2020/11/codebook_1990-2017_version_homepage. pdf. Accessed 11 Mar 2021.

Erdmann, Gero. 2011. Decline of democracy: loss of quality, hybridisation and breakdown of democracy. In Regression of democracy?, ed. Gero Erdmann, Marianne Kneuer, 21-58. Wiesbaden: VS.

Erdmann, Gero, and Marianne Kneuer. 2011. Introduction. In Regression of democracy?, ed. Gero Erdmann, Marianne Kneuer, 9-20. Wiesbaden: VS.

Eur-Lex. 2012. Treaty on the European Union. http://eur-lex.europa.eu/legal-content/EN/TXT/?uri=celex: 12012M049. Accessed 29 June 2016.

European Commission. 2020. European Public Prosecutor's Office. https://ec.europa.eu/anti-fraud/policy/ preventing-fraud/european_public_prosecutor_en. Accessed 11 Mar 2021.

European Council. 1993. Copenhagen Criteria. http://www.europarl.europa.eu/summits/copenhagen/co_ en.pdf. Accessed 29 June 2016.

European Council. 2020. European council meeting (10 and 11 december 2020)—conclusions. https:// www.consilium.europa.eu/media/47296/1011-12-20-euco-conclusions-en.pdf. Accessed 11 Mar 2021.

European Union. 2007. Consolidated versions of the treaty on European Union and the treaty on the functioning of the European Union. Treaty of Lisbon. official journal of the European Union (51). http:// www.lexnet.dk/law/download/treaties/Eut-2007-first.pdf. Accessed 14 Nov 2013.

Frankenberger, Rolf, and Graf Patricia. 2011. Elections, democratic regression and transitions to autocracy: lessons from Russia and Venezuela. In Regression of democracy?, ed. Gero Erdmann, Marianne Kneuer, 201-221. Wiesbaden: VS.

Freedom House. 2019. Freedom in the world 2019. Democracy in retreat. https://freedomhouse.org/report/ freedom-world/2019/democracy-retreat. Accessed 8 Mar 2021. 
Freedom House. 2020. Freedom in the world 2020. A leaderless struggle for democracy. https:// freedomhouse.org/report/freedom-world/2020/leaderless-struggle-democracy. Accessed 8 Mar 2021.

Ganev, Venelin I. 2013. Post-accession hooliganism: democratic governance in Bulgaria and Romania after 2007. East European Politics \& Societies 27(1):26-44.

Huntington, Samuel P. 1996. Democracy for the Long Haul. Journal of Democracy 7(2):3-13. http://muse. jhu.edu/journals/journal_of_democracy/v007/7.2huntington.html. Accessed 27.01.15.

IDEA. 2021. Taking stock of regional democratic trends in europe before and during the COVID-19 pandemic. https://www.idea.int/sites/default/files/publications/regional-democratic-trends-europebefore-and-during-COVID-19.pdf. Accessed 8 Mar 2021.

Jakab, András, and Lando Kirchmair. 2020. How to quantify a proportionate financial punishment in the new EU rule of law mechanism? https://verfassungsblog.de/how-to-quantify-a-proportionatefinancial-punishment-in-the-new-eu-rule-of-law-mechanism/. Accessed 11 Mar 2021.

Kapidžić, Damir. 2020. The rise of illiberal politics in Southeast Europe. Southeast European and Black Sea Studies 20(1):1-17.

Kelemen, R.D. 2017. Europe's Other Democratic Deficit: National Authoritarianism in Europe's Democratic Union. Government and Opposition 52(2):211-238. https:/www.cambridge.org/core/journals/ government-and-opposition/article/europes-other-democratic-deficit-national-authoritarianism-ineuropes-democratic-union/D0521BB6E422F3354315A5708C5161F7. Accessed 11.03.21.

Kelemen, R.D. 2020. The European Union's authoritarian equilibrium. Journal of European Public Policy 27(3):481-499. https://doi.org/10.1080/13501763.2020.1712455.

Keszthelyi, Christian. 2017. Hungary's economy heavily depends on EU funds, study finds. Budapest Business Journal. 2017. https://bbj.hu/budapest/culture/history/hungary-s-economy-heavily-dependson-eu-funds-study-finds. Accessed 11 Mar 2021.

Kneuer, Marianne. 2007. Demokratisierung durch die EU. Süd- und Ostmitteleuropa im Vergleich. Wiesbaden: VS.

Kneuer, Marianne. 2011. Deficits in democratic quality? The effects of party-system institutionalisation on the quality of democracy in central eastern europe. In Regression of democracy?, ed. Gero Erdmann, Marianne Kneuer, 133-171. Wiesbaden: VS.

Krastev, Ivan. 2018. Eastern Europe's illiberal revolution: the long road to democratic decline. Foreign Affairs 97(3):49-56.

Krekó, Péter, and Zsolt Enyedi. 2018. Orbán's Laboratory of Illiberalism. Journal of Democracy 29(3):39-51. https://muse.jhu.edu/article/698916/pdf. Accessed 12.01.19.

Kube, Vivian, Pauline Weller, Selmin Çalışkan, and Peter Matjašič. 2020. Shrinking Spaces in Deutschland, Shrinking Spaces in Europa. https://freiheitsrechte.org/home/wp-content/uploads/2020/12/ 201204_Paper_Layout.pdf. Accessed 11 Mar 2021.

Lang, Kai-Olaf. 2017. Can Brussels save democracy? The lacking effectiveness of EU democracy policy towards member states. In Common values: discussing German and Polish perceptions of European integration, ed. Weronika Priesmeyer-Tkocz, 13-30. Baden-Baden: Nomos.

Lauth, Hans-Joachim, Oliver Schlenkrich, and Lukas Lemm. 2021. Different types of deficient democracies: reassessing the relevance of diminished subtypes. International Political Science Review. https:// doi.org/10.1177/0192512121995686

Leuffen, Dirk, Berthold Rittberger, and Frank Schimmelfennig. 2013. Differentiated integration. Explaining variation in the European Union. Houndsmill, Basingstoke: Palgrave Macmillan.

Levitsky, Steven, and Lucan Way. 2015. The myth of democratic recession. Journal of Democracy 26(1):45-58. http://muse.jhu.edu/journals/journal_of_democracy/v026/26.1.levitsky.pdf. Accessed 30.01 .15 .

Lührmann, Anna, Lisa Gastaldi, Sandra Grahn, I. Lindberg Staffan, Laura Maxwell, Valeriya Mechkova, Richard Morgan, Natalia Stepanova, and Shreeya Pillai. 2019. Democracy facing global challenges. V-Dem Annual Democracy Report 2019. : V-Dem Institute.

Magyar, Bálint, and Bálint Madlovics. 2019. Ungarn: Ein Mafia-Staat kämpft für Straffreiheit. derStandard. 2019. https://www.derstandard.de/story/2000105427736/ungarn-ein-mafia-staat-kaempftfuer-straffreiheit. Accessed 11 Mar 2021.

Merkel, Wolfgang. 2004. Embedded and defective democracies. Democratization 11(5):33-58.

Merkel, Wolfgang. 2010. Systemtransformation. Eine Einführung in die Theorie und Empirie der Transformationsforschung, 2nd edn., Wiesbaden: VS.

Merkel, Wolfgang, and Hans-Jürgen Puhle. 1999. Von der Diktatur zur Demokratie. Transformationen, Erfolgsbedingungen, Entwicklungspfade. Opladen: Westdt. Verl..

Merkel, Wolfgang, Hans-Jürgen Puhle, Aurel Croissant, Claudia Eicher, and Peter Thiery. 2003. Theorie. Vol. 1. Wiesbaden: VS. 
Merkel, Wolfgang, Daniel Bochsler, Karima Bousbah, Marc Bühlmann, and Heiko Giebler. 2014. Democracy barometer. Methodology. Version 4. http://www.democracybarometer.org/Data/Methodical \%20Explanatory\%201990-2012.pdf. Accessed 21 Nov 2015.

Morlino, Leonardo. 2004. 'Good' and 'bad' democracies: how to conduct research into the quality of democracy. Journal of Communist Studies and Transition Politics 20(1):5-27.

Morlino, Leonardo, and G. Carli Luiss. 2014. How to assess a democracy. What alternatives? Moscow: HSE Publishing House. https://www.hse.ru/data/2014/03/25/1318948855/Morlino,\%20Carli-text. pdf. Accessed 25.04.2021

Morlino, Leonardo. 2009. Qualities of democracy: how to analyze them. http://indicatorsinfo.pbworks. com/f/Morlino+Qualities+of+Democracy. Accessed 2 July 2016.

Müller, Jan-Werner. 2013. Safeguarding Democracy inside the EU. Brussels and the Future of Liberal Order. Transatlantic Academy 2012-2013 (No. 3): 1-27. http://www.transatlanticacademy.org/sites/ default/files/publications/Muller_SafeguardingDemocracy_Feb13_web.pdf. Accessed 4 May 2014.

Munck, Gerardo L. 2016. What is democracy? A reconceptualization of the quality of democracy. Democratization 23(1):1-26. http://www.tandfonline.com/doi/abs/\%2010.1080/13510347.2014.918104? journalCode=fdem20. Accessed 29.06.16.

O’Donnell, Guillermo A. 1995. III. Do economists know best? Journal of Democracy 6(1):23-28. http:// muse.jhu.edu/journals/journal_of_democracy/v006/6.1odonnell.html. Accessed 10.04.15.

Osterberg-Kaufmann, Norma, Toralf Stark, and Christoph Mohamad-Klotzbach. 2020. Challenges in conceptualizing and measuring meanings and understandings of democracy. Zeitschrift für Vergleichende Politikwissenschaft 14(4):299-320.

Otto, Ferdinand. 2021. EU-Kommission startet neues Verfahren gegen Ungarn wegen NGO-Gesetz. Zeit Online. 2021. https://www.zeit.de/politik/ausland/2021-02/ungarn-ngo-gesetz-eu-kommissionverfahren-europaeischer-gerichtshof. Accessed 12 Mar 2021.

Pickel, Susanne, and Gert Pickel. 2006. Politische Kultur- und Demokratieforschung. Grundbegriffe, Theorien, Methoden : eine Einführung, 1st edn., Wiesbaden: VS.

Pickel, Susanne, Toralf Stark, and Wiebke Breustedt. 2015. Assessing the quality of quality measures of democracy: a theoretical framework and its empirical application. European Political Science 14(4):496-520.

Pickel, Susanne, Wiebke Breustedt, and Theresia Smolka. 2016. Measuring the quality of democracy: why include the citizens perspective? international political science review. http://ips.sagepub.com/ content/early/2016/05/21/0192512116641179.full.pdf+html. Accessed 4 July 2016.

Puddington, Arch. 2008. Freedom in retreat : is the tide turning? https://freedomhouse.org/report/freedomworld-2008/essay-freedom-retreat. Accessed 29 Jan 2017.

Puddington, Arch. 2011. Democracy under duress. Journal of Democracy 22(2):17-31.

Sapper, Manfred, and Volker Weichsel (eds.). 2018. Unterm Messer. Der illiberale Staat in Ungarn und Polen. Berlin: Berliner Wissenschafts-Verlag.

Scheppele, Kim L., Laurent Pech, and Sébastien Platon. 2020. Compromising the rule of law while compromising on the rule of law. https://verfassungsblog.de/compromising-the-rule-of-law-whilecompromising-on-the-rule-of-law/. Accessed 11 Mar 2021.

Schimmelfennig, Frank. 2009. The normative origins of democracy in the European Union: toward a transformationalist theory of democratization. http://www.nccr-democracy.uzh.ch/publications/ workingpaper/pdf/WP39.pdf. Accessed 26 July 2017.

Schmitter, Philippe C. 2015. Crisis and transition, but not decline. Journal of Democracy 26(1):32-44. http://muse.jhu.edu/journals/journal_of_democracy/v026/26.1.schmitter.pdf. Accessed 30.01.15.

Siaroff, Alan. 2009. Comparing Political Regimes. A thematic introduction to comparative politics. Toronto: University of Toronto Press.

Smolka, Theresia. 2019. Belastungsprobe für die Europäische Union. Veränderung der Demokratiequalität in den 27 Mitgliedstaaten zwischen 2004 und 2012, 1st edn., Wiesbaden: Springer. Imprint: Springer VS.

Svolik, Milan. 2008. Authoritarian reversals and democratic consolidation. American Political Science Review 102(02):153-168.

Vachudova, Milada A. 2020. Ethnopopulism and democratic backsliding in Central Europe. East European Politics 36(3):318-340. https://doi.org/10.1080/21599165.2020.1787163.

Walker, Christopher, and Sylvana Habdank-Kolaczkowska. 2012. Fragile frontier: democracy's growing vulnerability in central and southeastern europe. https://freedomhouse.org/sites/default/files/2020-02/ NIT_2012_Booklet_0.pdf. Accessed 25.04.2021.

Ziemer, Klaus. 2020. Ursachen der unterschiedlichen Entwicklung demokratischer Standards in den postkommunistischen Staaten Europas. Zeitschrift für Vergleichende Politikwissenschaft 14(4):247-267. 